\title{
Microelectronic Gas sensors for Non-invasive Analysis of Exhaled Gases
}

\section{Aroutiounian $\mathrm{VM}^{*}$}

\author{
Yerevan State University YSU, 1 Alex Manoukian Str, Armenia
}

\begin{abstract}
Interest in the research of small-sized gas sensors (especially semiconductor) for medical applications has sharply increased in recent years. Requirements for to such sensors are their high sensitivity, performance and stability to very low concentrations of gases, mainly exhaled by a living organism. Today the doctor not only polls, and examines the patient but also sends it to the lab-tests of blood, urine, perform an electrocardiogram, etc. But, for example, today's periodic monitoring of glucose concentrations in the blood induces acute pain, risk of virus (e.g., hepatitis B) infection from needles, and other difficulties in frequent monitoring. Even in 1784, Antoine Lavoisier wrote that of all the phenomena of life, none is more striking and worthier for physicists and physiologists than phenomena accompanying the breath. Meanwhile, one of the most important directions of modern medicine is non-invasive diagnostics of the patient, based on the analysis of exhaled air in a special device.
\end{abstract}

Keywords: Microelectronic semiconductor gas sensor; Breath analysis; Metal oxide

\section{INTRODUCTION}

We are talking about the exhaled air, its chemical composition, and volatile substances from the human body through the lungs. It is only necessary to make exhalation and after a few seconds or minutes to get the results of the analysis. The prospect of an noninvasive diagnosis is obvious - no unpleasant sensations, there is full safety from viral hepatitis, AIDS and other infections [1].

Exhaled breath contains about 1000 volatile organic compounds (VOCs) that are the products of metabolism. The exhaled gases such as $\mathrm{NO}_{\mathrm{x}}$, acetone, ethanol, $\mathrm{NH}_{3}, \mathrm{H}_{2} \mathrm{~S}$, and $\mathrm{H} 2 \mathrm{O} 2$ can be used as sensors to diagnose various diseases. Several important gases having immediately dangerous to life or health concentration in air. For example, the threshold limit value for ethanol and acetone are 1000 and 750 ppm, correspondingly. Depending on the level of the basic exchange, a person releases through the lungs on average about 5 to 18 liters of carbon monoxide $\mathrm{CO}$ and 50 grams of water per hour. And with them - a huge number of micro-impurities volatile compounds. That is, a multi-component gas mixture formed, which accumulates first in the alveolus of the lungs. It is necessary to look for the cause of this either in incoming food (sources of volatile substances), or in internal organs, blood, blood vessels, sweat or urine.

According to the results of the study of volatile substances exhaled by a person, it is possible to judge the nature of nutrition - sufficiency of carbohydrates, excess fat and alcohol. By excess or lack of any chemical component in the spectrum of exhaled air, hereditary enzymopathy and the presence of various diseases can also be assumed. Due to the large surface of the lungs, volatile substances (ethanol, ammonia, acetone, and others) very quickly pass from the bloodstream to the external environment with exhaled air. It is the mixture of various molecules secreted by man that makes up the individual, unique smell of the patient. In a number of cases, this smell allows to immediately make the correct diagnosis. The sweet "liver odor" of explosives is due to a violation of the exchange of aromatic compounds and the accumulation of the product of the conversion of methionine - methyl mercaptan. This smell of raw liver often haunts pancreatic cancer patients and may be one of the first symptoms of this ailment. The smell of ammonia in explosives is typical for kidney and uremia diseases, the "mouse smell" - for patients with hereditary phenylketonuria, the smell of syrup is in violation of the metabolism of fatty acids and the accumulation of keto acids and amino acids in the blood and urine, the smell of acetone - in patients with diabetes mellitus. A sharp specific smell from the mouth is a symptom of a number of diseases of the oral cavity and stomach (stomatitis, periodontal disease, gastritis, peptic ulcer, and stomach cancer). In cardiopulmonary insufficiency, unpleasant sour smell of under oxidized metabolic products associated with incomplete combustion of proteins, fats, and carbohydrates in the liver often comes from patients. An unusual persistent smell is a formidable symptom of a growing tumor of the anterior brain. It turned out that with a stroke with an unfavorable outcome, much less acetone is released in patients than in healthy people. At the same time, diabetics, who also fell

"Correspondence to: Aroutiounian VM, Yerevan State University YSU, 1 Alex Manoukian Str, Armenia, Tel: +37410555590; E-mail: aroutiounv1@gmail.com

Received: Nov 25, 2019; Accepted: Jun 10, 2020; Published: Jun 27, 2020

Citation: V. M. Aroutiounian (2020) Microelectronic Gas sensors for Non-invasive Analysis of Exhaled Gases. J Nanomed Nanotech. 11:544. doi: $10.35248 / 2157-7439.19 .11 .544$

Copyright: (C2020 Aroutiounian VM. This is an open-access article distributed under the terms of the Creative Commons Attribution License, which permits unrestricted use, distribution, and reproduction in any medium, provided the original author and source are credited. 
into a coma, exhale tens and hundreds of times more acetone than healthy ones. The content of acetone and ethanol is significantly different from healthy individuals (in patients with diabetes mellitus, cardiovascular disease, in children with bronchial asthma, diathesis, in pregnant women with toxicosis of the first half of pregnancy). We also note that it is possible to successfully detect using semiconductor sensors odorless substances, such as carbon monoxide (carbon monoxide) or carbon dioxide.

Capabilities of detection of various diseases using the analysis of the breath are discussed below.

Data on the surveillance capabilities of diseases in the allocation of specific gases are collected below in Table $1[1,2]$. Naturally, assembled here material cannot be considered as exhaustive one. Note also that the analysis of the breath allows to detect (diagnose) cancer of stomach and ovaries, rheumatoid disease, acute myocardial infarction, gum disease, tooth decay, bacterial imbalance on the tongue, impacted wisdom teeth, dehydration, sleep apnea, gastrit, stomach ulcers duodenal ulcers and other diseases can be carried out.
It is known that a qualitative breakthrough in studying the composition of explosives was made only at the beginning of the 20th century, when mass spectrography (MS) (Thompson, 1912) and chromatography began to be used. The revival of chromatography is associated with the names of the English scientists Martin and Sing, who in 1941 developed the method of distribution chromatography, for which they were awarded the Nobel Prize in chemistry in 1952. From the middle of the 20th century to the present day, chromatography and mass spectrograph are among the most widely used analytical methods for studying explosives. About 1000 volatile metabolites were determined by these methods in explosives, many of which are used as markers of inflammation [1]. Their specificity and sensitivity for the diagnosis of many diseases are determined. In addition to chromatography and mass spectrograph, radioimmune and enzyme-linked immunosorbent assays, spectrophotometry, fluorometric and chemiluminescent methods are used, the protein matrix and tumor necrosis factor are studied, etc. In medicine, when studying gas exchange, gas analyzers are used to measure the concentration of carbon dioxide, oxygen, and nitrogen in the inhaled and the exhaled gas mixture,

Table 1: Gases and exhalation and diagnostic significance.

\begin{tabular}{|c|c|}
\hline Gases & Exhalation and diagnostic significance \\
\hline Nitrogen oxide (NO) & $\begin{array}{l}\text { Respiratory diseases [asthma, chronic obstructive pulmonary disease (COPD), etc.] Rhinitis digestive diseases } \\
\text { [inflammation in the stomach (gastritis, hepatitis, colitis), including infection Helicobacter pylon digestive } \\
\text { cancer] Hyperthermia Heavy-textured sepsis Uremia }\end{array}$ \\
\hline Carbon monoxide (CO) & $\begin{array}{c}\text { Anemia (hemolytic, sideroblastic cell) Carboxy hemoglobinamija in acute and chronic exposures Lasting } \\
\text { stay at intakes Giperbilirubinonemia of newborn oxidative stress hematoma Hemoglobinuria Pre-eclampsia } \\
\text { of infection Thalassemia respiratory diseases (asthma, COPD, infections of the respiratory infection } \\
\text { Inflammation of lung) }\end{array}$ \\
\hline Ammonia $\left(\mathrm{NH}_{3}\right)$ & $\begin{array}{l}\text { Diseases of the kidneys and liver (renal insufficiency in nephritis, idiopathic hypertension, atherosclerosis of } \\
\text { renal artery, toxicosis and nephropathy of pregnant, toxic defeats of kidneys, paucity of the liver in jaundice, } \\
\text { hepatitis, cirrhosis of the liver, toxic hepatitis) Acute and chronic radiation sickness The metabolism of } \\
\text { monoamine in light Uremia }\end{array}$ \\
\hline Hydrogen $\left(\mathrm{H}_{2}\right)$ & $\begin{array}{c}\text { Diseases of bodies of digestion (digestive disorders of infants Gastrointestinal Disorders anaerobic bacteria in } \\
\text { the large intestine Malabsorption hydrocarbons) }\end{array}$ \\
\hline ydrogen Peroxide $\mathrm{H}_{2} \mathrm{O}_{2}$ & $\begin{array}{l}\text { Respiratory diseases (asthma, chronic obstructive pulmonary disease (COPD), lung cancer, weakened } \\
\text { respiratory lung function, etc.) The acute and chronic radiation sickness Diabetes }\end{array}$ \\
\hline Methane & Gastrointestinal disorders (Malabsorption hydrocarbons) Colorectal cancer \\
\hline $\mathrm{CS}_{2}$ and pentane & Risk factor in coronary artery diseases, Schizophrenia \\
\hline Ethylene $\left(\mathrm{C}_{2} \mathrm{H}_{4}\right)$ & $\begin{array}{l}\text { Oxygen stress, Lipid peroxidation internals at acute myocardial infarction Destruction caused by free radicals } \\
\text { Uremia }\end{array}$ \\
\hline Ethane $\left(\mathrm{C}_{2} \mathrm{H}_{6}\right)$ and pentane & $\begin{array}{c}\text { Lipid peroxidation in liver transplant peroxide Marker-assisted oxidation of lipids Schizophrenia COPD } \\
\text { Interstinal lung desease Asthma Cystic fibrosis Heart failure Inflammatory bowel disease }\end{array}$ \\
\hline Methanol & Diseases of the central nervous system Lung and breast cancer \\
\hline Ethanol & Diabetes \\
\hline Acetone $\mathrm{C}_{6} \mathrm{H}_{6} \mathrm{O}$ & $\begin{array}{l}\text { Alcoholism, the function of the pancreas in acute pancreatitis and execute-destructive dietary and severe } \\
\text { balance failure at lung cancer Diabetes Chronic liver disease }\end{array}$ \\
\hline Isotopic modification & $\begin{array}{l}\text { Infection with the bacterium Helicobacter pylori passage of food through the gastrointestinal tract the } \\
\text { overgrowth of bacteria lactose Digestion pancreatic Dysfunction Malabsorption liver dysfunction, including } \\
\text { cirrhosis the metabolism of bile glucose metabolism }\end{array}$ \\
\hline Vapors of urine & Gastroenterology \\
\hline Pentane and its Derivatives & $\begin{array}{c}\text { Breath and lung cancer. Acute myocardial infarction Heart titrant rejection Rheumatic arthritis The } \\
\text { exacerbation of asthma }\end{array}$ \\
\hline Alkanes (hexane, etc.) & Lung cancer Tuberculosis \\
\hline Dimethyl and carbonyl sulfides & Lung cancer Cystic fibrosis Intra- and extraoral halitosis Chronic liver disease Hypermethioninemia \\
\hline Isoprene & Lung cancer Castaic ulcer Heart failure \\
\hline Hydrogen sulfide & Intraoral halitosis \\
\hline $\begin{array}{l}\text { Heptane, xylenes, octane, ethylbenzene, } \\
\text { styrene, decane, toluene, benzene, } \\
\text { gaseous aldehyde and formaldehyde }\end{array}$ & Lung cancer \\
\hline
\end{tabular}


to study blood gases and to measure the concentration of the indicator gas in the artificially created mixture when determining a number of respiration parameters (instruments for measuring gas concentration in a gas mixture). In recent years, ionic and proton mass spectroscopic methods and gas chromatography have been used in medicine, but such equipment is expensive and bulky

Of course, the possibility of physical-chemical studies of gas- phase are not limited to the analysis. Samples of internal abdominal gases can collect and examine from different sections of the bronchi with bronchoscopy, from the stomach with gastroscopy, from the colon with colonoscopy, from the bladder with cystoscopy, from the uterus during hysteroscopy. Today we are talking about the possibility of developing individual metabolic profile of the patient.

The use of semiconductor gas sensors for detecting the concentration of detectable gas released in patients (acetone in diabetes, for example) is widely discussed in the literature [3-5]. Determination of the concentration of chemical compounds in explosives using gas sensors will allow the diagnosis of the disease already in the early stages and will make it possible to control treatment. In addition to nitrogen, oxygen, and water vapor, explosives contain various gases in a sick person. By the concentration of acetone and the amount of current or voltage passing through the semiconductor sensor, for example, one can judge the degree of diabetes, acute heart failure, lung cancer; hydrogen peroxide and nitric oxide-asthma and other pulmonary diseases, cancer of the digestive system; ammonia and hydrogen sulfide - hepatitis and cirrhosis; hydrogen and methane, a number of diseases of the digestive system, etc.

The current study of head, ovarian, bladder, prostate, kidney, gastric, and neck cancer, Crohn's disease, ulcerative colitis. idiophatic and atypical Parkinson's, multiple sclerosis, pulmonary hypertension and other diseases is started now using nanoarrays and artifical intelligence methods.

Metal oxide semiconductors n-type $\mathrm{SnO}_{2}, \mathrm{ZnO}, \mathrm{WO}_{3}, \mathrm{TiO}_{2}, \mathrm{MoO}_{3}$, $\mathrm{In}_{2} \mathrm{O}_{3}, \mathrm{Fe}_{2} \mathrm{O}_{3}$ and p-type $\mathrm{CuO}, \mathrm{NiO}, \mathrm{Cr}_{2} \mathrm{O}_{3}, \mathrm{Mn}_{3} \mathrm{O}_{4}$ are used during breath analysis [1,2,6-12], Haick et al. [13,14], Di Natale et al. [15], Righettoni et al. [16], and Kim et al. [17]. Some interesting papers about breath analysis listed in Refs. [18-32]. Note that the disease diagnosis using exhaled breath is still in the nascent stage and needs further improvement for clinic applications.

\section{DETECTION OF $\mathrm{NO}_{2}$ AND $\mathrm{NH}_{3}$ FOR THE DIAGNOSIS OF ASTHMA AND RENAL DISEASE}

Villi-like $\mathrm{WO}_{3}$ nanostructures show high gas responses $\left(\mathrm{R}_{\mathrm{ga}} / \mathrm{R}_{\text {air }}\right)$ $\sim 30$ to $0.2 \mathrm{ppm} \mathrm{NO}$ at $200^{\circ} \mathrm{C} \mathrm{[33].} \mathrm{It} \mathrm{is} \mathrm{shown} \mathrm{also} \mathrm{in} \mathrm{[34]} \mathrm{that}$ $\mathrm{WO}_{3}$ nanotubes exhibit high responses to $1 \mathrm{ppm}$ NO. These results were obtained in highly humid ( $\mathrm{RH}>80 \%$ ) atmospheres. BOSCH Healthcare Solutions announced a monitor which allowing measurements of fractional exhaled nitric oxide (FENO) for the diagnosis of asthma [35]. Therefore, the potential of $\mathrm{WO}_{3}$ nanostructures for the diagnosis of asthma was demonstrated. This device consists of pretreatment components that precondition the exhaled gas and sensing components that measure FENO.

The initial stages of renal disease can be diagnosed by measuring $\mathrm{NH}_{3}$ vapor in exhaled breath [36]. End-stage renal disease (ESRD) requires time-consuming, expensive, and inconvenient hemodialysis, which significantly decreases the quality of life for patients. If the nephron function is completely lost, kidney transplantation needs to be considered. The breath $\mathrm{NH}_{3}$ concentration of ESRD patients ranges around $4,9 \mathrm{ppm}$ in contrast to $0.96 \mathrm{ppm}$ for healthy individuals [37]. Exhaled ammonia can be also used to diagnose liver disease [38] and helicobacter pylori infection [39].

[- $-\mathrm{MoO}_{3}[40]$ and Si-doped $\mathrm{MoO}_{3}$ [41] have high selectively to $\mathrm{NH}_{3}$ detection at sub-ppm levels even in highly humid atmospheres, and can used for diagnosis of renal failure. $\mathrm{MoO}_{3}$ thin films [4244], $\mathrm{WO}_{3}$ thin films with $\mathrm{Pt}-\mathrm{SiO}_{2}$ overlayers [45], and Cr-doped $\mathrm{WO}_{3}$ films $[46,47]$ have been reported to exhibit $\mathrm{NH}_{3}$-detection selectivity in a dry atmosphere. $\mathrm{MoO}_{3}$ and $\mathrm{WO}_{3}$ often show high response to basic amines such as trimethylamine, triethylamine, and butylamine [48-50].

\section{DETECTION OF ACETONE FOR DIAGNOSING DIABETES}

Diabetes patients use fat instead of glucose for energy and ketones are produced by the liver during fatty-acid metabolism. The concentrations of breath acetone in diabetes patients are reported to be higher than $1.8 \mathrm{ppm}$ while those of healthy people are lower than $0.8 \mathrm{ppm}$ [51]. Breath acetone concentrations can increase during ketogenic or low carbohydrate diets that are known to induce ketosis [52]. It allows checking the effectiveness of ketosisbased dietary programs for healthy people [53].

Among all other sensing materials, metal oxides show the highest responses to acetone. Various oxide sensing materials mentioned below allow to enhance selectivity and sensitivity to acetone under highly humid atmospheres.

There are $\mathrm{Pt}, \mathrm{Rh}$ or Ni-loaded $\mathrm{WO}_{3}$ hemitubes/nanofibers, having an average size of 2 to $3 \mathrm{~nm}$ [54-57], Si-doped $\varepsilon-\mathrm{WO}_{3}$ [58-60], Ptloaded $\mathrm{SnO}_{2}$ nanotubes/ hierarchical nanofibers [61,62], Pd-loaded $\mathrm{ZnO} / \mathrm{ZnCo}_{2} \mathrm{O}_{4}$ hollow spheres [63], $\mathrm{RuO}_{2}$-loaded $\mathrm{WO}_{3}$ nanofibers [64], $\mathrm{Rh}_{2} \mathrm{O}_{3}$-loaded $\mathrm{WO}_{3}$ nanofibers [65], and PdO-loaded $\mathrm{Co}_{3} \mathrm{O}_{4}$ hollow nanocages [66]. These fabricated nanostructures show great promise to be utilized as portable breath sensors for diabetes disease diagnosis.

Note that $\mathrm{SnO}_{2}, \mathrm{ZnO}, \mathrm{Fe}_{2} \mathrm{O}_{3}$, and other metal oxide gas sensors often show similar responses to acetone and ethanol [67-69]. Accordingly, analyses from intoxicated diabetes patients, or the presence of small amounts of alcohol in the mouth, may not provide reliable diagnoses. Pure and catalyst loaded $\mathrm{WO}_{3}$ have been used as the most common and representative sensing materials for the selective detection of acetone [54-65].

\section{DETECTION OF H2S FOR DIAGNOSING HALITOSIS}

The degradation of S-containing amino acids in the oral cavity, upper/lower respiratory tract and alveolar exchange with blood lead to halitosis. It is detectable as highly odorous gases with concentrations less than $1 \mathrm{ppm}$, that can be used to diagnose fetor hepaticus and metabolic disorder.

$\mathrm{CuO}$ alone and as additive materials to $\mathrm{SnO}_{2}, \mathrm{In}_{2} \mathrm{O}_{3}$, and $\mathrm{ZnO}$ has been used as sensing material. The conversion of the p-type semiconducting $\mathrm{CuO}$ into metallic $\mathrm{CuS}$ leads to form of junction n-type semiconductor-metallic $\mathrm{CuS}$. The doping of hollow $\mathrm{SnO}_{2}$ spheres with $\mathrm{CuO}$ decreased the humidity dependence of the sensing characteristics to negligible levels without sacrificing high selectivity and sensitivity $\mathrm{H}_{2} \mathrm{~S}$ at $80 \% \mathrm{RH}$. Therefore, $\mathrm{CuO}$ is effective both in dry air and exhaled breath.

Liang et al. [70] reported that the CuO-loaded $\mathrm{In}_{2} \mathrm{O}_{3}$ nanofiber sensor showed reversible $\mathrm{H}_{2} \mathrm{~S}$ sensing characteristics above $300^{\circ} \mathrm{C}$. 
Doping Mo on $\mathrm{ZnO}$ nanowires not only increased selectivity to $\mathrm{H}_{2} \mathrm{~S}$ but also significantly enhanced the reversibility of the $\mathrm{H}_{2} \mathrm{~S}$ sensing characteristics. Ag was also reported to be an effective additive that enhanced the $\mathrm{H}_{2} \mathrm{~S}$ selectivity of sensors based on $\mathrm{SnO}_{2}[71,72]$, $\mathrm{TiO}_{2}$ [73], and $\mathrm{Fe}_{2} \mathrm{O}_{3}$ [74]. Yoneda et al. [75] provided a mini review on various techniques for the analysis of halitosis.

\section{DETECTION OF VOLATILE ORGANIC COMPOUNDS FOR LUNG CANCER DIAGNOSIS}

Researchers have investigated different gases of lung cancer by comparing the breaths of healthy people and lung cancer patients [76-80]. Volatile organic compounds (VOCs) are reported as biomarker gases of lung cancer. Comprehensive review on VOCs related to lung cancer has been provided by Hakim et al. [81]. Note that most lung-cancer biomarker gases, except a few, contain benzene rings. Pure CNT or graphene-based sensing materials generally do not exhibit notable responses to large gases at room temperature or temperatures less than $100^{\circ} \mathrm{C}$.

P-type semiconductors as gas sensing materials for benzene-derived gases, such as xylene, toluene, and benzene itself, can be used during measurements of lung cancer.

Gaseous aldehyde and formaldehyde breath biomarkers of lung cancer were proposed [82]. Ni-doped and Co-doped $\mathrm{ZnO}$ nanowires, $\mathrm{Co}_{3} \mathrm{O}_{4}$ (mesoporous, $\mathrm{Cr}$-doped nanocomposites, and Pd-loaded shell sphere and hierarchical nanosheets), $\mathrm{Cr}_{2} \mathrm{O}_{3}$ $\mathrm{ZnCr}_{2} \mathrm{O}_{4}$ nanocomposites, $\mathrm{NiO}_{-} \mathrm{NiMoO}_{4}-\mathrm{SnO}_{2}$ nanocomposites, Cr-doped $\mathrm{NiO}$ hierarchical nanosheets, $\mathrm{Pd}-\mathrm{SnO}_{2}$ film with $\mathrm{Co}_{3} \mathrm{O}_{4}$ overlayer are very promising materials for detection of lung cancer. [3].

Of course, lung cancer can be diagnosed via the detection of a single biomarker gas. However, to increase diagnosis precision, the diagnosis of lung cancer using the electronic nose technology is preferable. Note also that pretreatment components such as dehumidifiers, preconcentrators, and flow sensors are very important for precise analysis. To miniaturize the system and achieve in situ diagnosis, the adsorption of analyte gases, interference gases, and moisture needs to be significantly improved [3].

\section{DETECTORS OF GASES}

An intensive work has been started on a manufacture of corresponding new small-sized equipment using semiconductor gas sensors. Note that at Yerevan State University (Department of Semiconductor Physics and Microelectronics and the Scientific Center for Semiconductor Devices and Nanoelectronics) as a result of many years of research, semiconductor sensors of various gases have been developed. Sensors at YSU are sensitive to vapors of acetone, ammonia, nitrogen oxides, iso-butane, ammonia, hydrogen sulfide, hydrogen, various alcohols, toluene, combustible gases, hydrogen peroxide, propane, propylene glycol, formaldehyde, dimethylformamide, dichloroethane, gasoline, carbon monoxide and smoke arising in the early stages of a fire (see some references [83-98]). As part of a NATO grant, small-sized semiconductor sensors for nerve gases of chemical weapons (sarin, mustard gas) have been developed in YSU. Successful tests of such sensors were carried out at the Czech Military Academy.

Of course, there is information about commercial gas sensors (except for military, poisonous and a number of industrial gases) produced in the USA, Japan, China, Russia and Germany. Note that the sensors at YSU are stable in time, of smaller volume, much cheaper than produced in above-mentioned countries and are easily compatible with integrated circuits

Figures 1-3 show our small-sized detectors of hydrogen and alcohols $[83,99,100]$. Figure 3 shows the possibility of implementing such a detector using a programmable board and the Arduino Nano memory. There are a couple of dozen contacts on the board, to which you can connect not only a number of chemical gas sensors developed by us but also all kinds of components: displays, LEDs, other sensors, motors, routers, magnetic locks, etc. It is possible to load a program into the Arduino processor that will control all of these devices according to a given algorithm. The Arduino board provides extensibility and the ability to automate certain activities. Thus, the realization of the electronic nose is possible, allowing the detection of several diseases. It is noteworthy that as a gas sensor can be used as sensors proposed in the center of semiconductor devices and nanotechnology of YSU, as well as any other, for example, Chinese gas sensors. In addition to the Arduino board
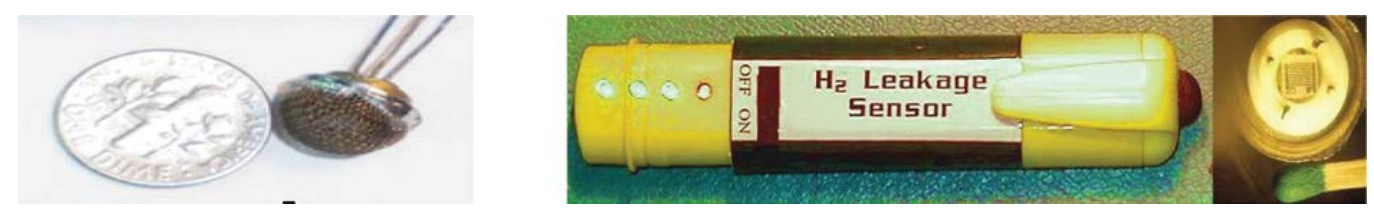

Figure 1: Hydrogen leakage sensor [84].

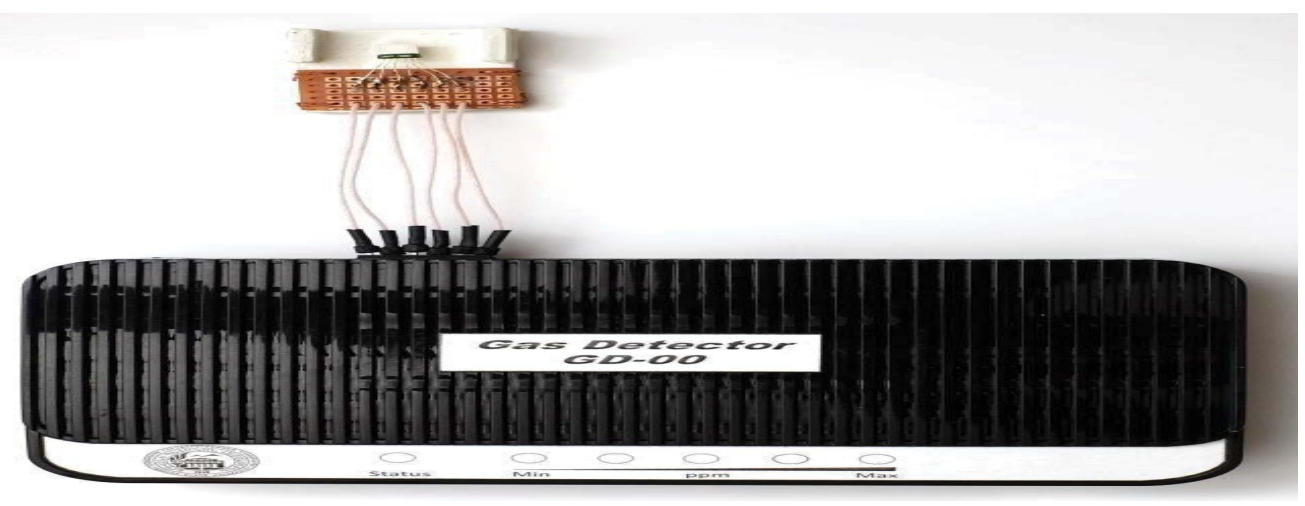

Figure 2: Ethanol sensor [100]. 


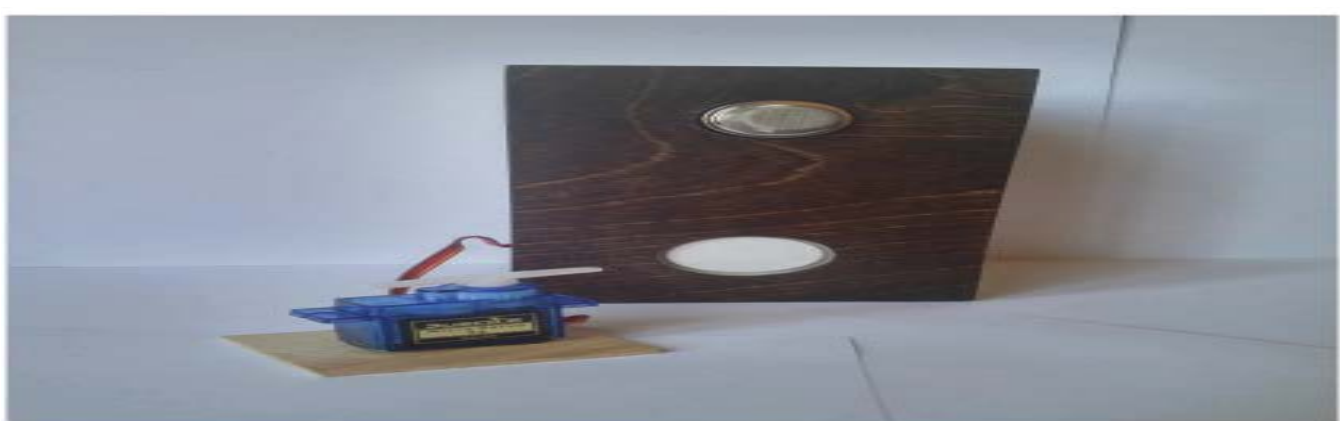

Figure 3: Arduino Nano Sensor [101].

and the gas sensor, we needed an alarm system, a servo drive that will simulate a valve, and a relay. We also added two buttons - the first one to turn the system on and off, and the second one to turn the servo on and off. The entire system is powered by six finger batteries or an AC-DS adapter. Earlier, we developed also a device, which allows us to measure simultaneously three gases - methane, carbon monoxide, and hydrogen.

Based on the sensors available at YSU, we are already developing testers for several diseases and gases for medical applications using explosives. Currently, work is underway to create devices with displays, indications of the degree of disease of which must be carefully established with the participation and help of medical doctors.

\section{CONCLUSIONS}

One of the most important directions of modern medicine is noninvasive diagnostics of the patient, based on the analysis of exhaled air in a special device. Data on the surveillance capabilities of various diseases in the allocation of specific gases are collected. The potential of various semiconductor chemical resistors made from metal oxide semiconductors to diagnose disease has been reviewed. For disease diagnosis from exhaled breath, pure and catalyst-loaded semiconductor chemical resistors sensing materials for specific biomarker gases are reported. In particular, nanosensors were discussed having the potential to detect asthma, renal disease, diabetes, halitosis, and lung cancer. The humidity and temperature dependencies of various sensing characteristics need to be decreased to negligible levels through the complete understanding of gassensing mechanisms and the interaction between moisture and the sensing surface. Corresponding low-cost detectors are developed which can detect small concentrations of exhaled air.

\section{REFERENCES}

1. Aroutiounian VM. Diagnostics using microelectronic semiconductor gas sensors. Reports of Natl. Acad. Sci. Armenia. 2019;9:264-273.

2. Konvalin G, Haick H. Sensors for breath analysis: From nanomaterials to compressive disease detection Supporting Information. 2019: Israel Institute of Technology: Israel.

3. Yoon JiW, Lee JH. Towards breath analysis on a chip for disease diagnostics using semiconductor-based chemiresistors: Recent progress and future perspectives. Lab on a chip. 2017;1:8-12.

4. Aroutiounian VM. Metal oxide nanosensors. J. Cont. Phys.-Arm. Acad. Sci. 2009;54:324-340.

5. Nasiri N, Clark Ch, Nanostructured sensors for medical and health applications: Low to high dimensional materials. Biosensors. 2019;9:43-65.

6. Costello BL, Amann A, Al-Kateb H, Flynn C, Filipiak W, Khalid T, et al. A review of the volatiles from the healthy human body. J. Breath Res. 2014;8:014001.
7. Miekisch W. Schubert J, Noeldge-Schomburg GFE. Diagnostic potential of breath analysis-focus on volatile organic compounds. Clin. Chim. Acta. 2004;347:25-39.

8. Buszewski B, Kesy M, Ligor T, Amann A. Human exhaled air analytics: biomarkers of diseases. Biomed. Chromatogr. 2007;21:553-566.

9. Manolis A. Human exhaled air analytics: biomarkers of diseases. Clin. Chem. 1983;29:5-15.

10. Cao C, Duan Y. Breath Analysis: Potential for Clinical Diagnosis and Exposure Assessment. Clin. Chem. 2006;52:800-811.

11. Kharitonov SA, Barnes PJ. Biomarkers of some pulmonary diseases in exhaled breath. Biomarkers. 2002;7:1-32.

12. Amann A, Španĕl P, Smith D. Breath analysis: the approach towards clinical applications. Mini-Rev. Med. Chem. 2007;7:115-129.

13. Vishinkin R, Haick H. Nanoscale Sensor Technologies for Disease De on via Volatolomics. Small. 2015;12:6142-6164.

14. Broza YY, Haick H. Nanomaterial-based sensors for detection of disease by volatile organic compounds. Nanomedicine. 2013;8:785-806.

15. Di Natale C, Paolesse CD, Martinelli EM, Capuano R. Solid-state gas sensors for breath analysis: a review. Anal. Chim. Acta. 2014;824:1-17.

16. Righettoni M,. Amann A, Pratsinis SE, Kim SJ, Choi SJ, Jang JS, Cho $\mathrm{HJ}$. Breath analysis by nanostructured metal oxides as chemo-resistive gas sensors. Mater. Today. 2015;18:163-171.

17. Kim. ID, Choi S J, Jang JS, Cho HJ. Acc. Chem. Rec. 50 (2017), 1587-1596.

18. Pal RB, Gurung A, Bhutia SD. Breathe carkers in health and disease. Asian J. Biomed. Pharmac. Sci. 2013;3:1-5.

19. Dweik RA, Amann A. Exhaled breath analysis: the new frontier in medical testing. J. Breath Res. 2008;2:2-11.

20. Nagaraja C, Shashibhushan BL, Asif M. Hydrogen peroxide in exhaled breath condensate (EBC): A clinical study. Lung India. 2012;29:123-127.

21. Narjinary M, Sen P, Pal M. Enhanced and selective acetone sensing properties of $\mathrm{SnO}_{2}$-MWCNT Nanocomposites. Promising materials for diabetes sensor. Materials and Design. 2017;115:158-164.

22. Thati A, Biswas A, Roy Sh. Breath acetone-based non-invasive detection of blood glucose levels. Intl. J. Smart Sens. Intel. Syst. 2015;8:1244-1260.

23. Saas V, Malwel T, Beukes M. Sensing technologies detection of acetone in human breath for diabetes diagnosis and monitoring. Diagnostics. 2018;8:12-29.

24. Lin T, LvX, Hu Z. Semiconductor metal oxides as chemoresistive sensors for detecting volatile organic compounds. Sensors. 2019;19:233-265.

25. Romero-Ben E. Surface modulation of single-walled carbon. Int. J. Nanomed. 2019;4:3245-3263.

26. Ghoshal S, Mitra D, Roy S. Biosensors and Biochips for nanomedical applications. A Review. Sens. Transd. J. 2010;113:1-17. 
27. Hill1 D, Binions R. Breath analysis for Medical diagnosis. Intl. J. Smart Sens. Intel. Syst. 2012;5:401-440.

28. Nasiri N, Clarke C. Nanostructured chemiresistive gas sensors for medical applications. Sensors. 2019;19:462 -478.

29. Cao F, Li C, Li M. $\mathrm{ZnO}$ nanorod walled carbon nanotube nanocomposite for ethanol vapour detection. Micro. Nano Lett. 2018;13:779-783.

30. Gonzales WV, Mobashsher AT, Abbosh A. The Progress of glucose monitoring. A review of invasive to minimally and non-invasive techniques, devices, and sensors. Sensors. 2019;19:800-845.

31. Kien N, Hung C, Ngoc MTM. Low-temperature prototype hydrogen sensors using $\mathrm{Pd}$ decorated $\mathrm{SnO}_{2}$ nanowires for exhaled breath applications. Sens. Actuators 2017;B253:156-163.

32. Güntner AT, Righettoni M, Sotiris PE. Selective sensing of $\mathrm{NH}_{3}$ by $\mathrm{Si}$ doped a-MoO ${ }_{3}$ for breath analysis. Ibid. 2016;B223:266-273.

33. Jornet N, Martíneza B, Cassi JCT. Towards sarcosine determination in urine for prostatic carcinoma detection. Ibid. 2019;B 287:380-389.

34. Moon HG, Choi YR, Shim YS, Choi KI, Lee JH, Kim JS et al. Vertically ordered $\mathrm{SnO}_{2}$ nanobamboos for substantially improved detection of volatile reducing gases. ACS Appl. Mater. Interfaces. 2013;5:10591. 10596.

35. Koo WT, Choi SJ, Kim NH, Jang JS, and Kim I.-D. Toward breath analysis on a chip for disease diagnosis using semiconductor-based chemiresistors: recent progress and future perspectives. Sens. Actuators. 2016;B223:301-310.

36. Krisnan ST. Devadhasan JP, Kim S. On the importance of accurate quantification of individual volatile metabolites in exhaled breath. Anal. Bioanal. Chem. 2017;409:21-27.

37. Davies S, Spanel P, Smith D. Quantitative analysis of ammonia on the breath of patients in end-stage renal failure. Kidney Int. 1997;52:223-228.

38. Dubois S, Eng S, Bhattacharya R, Rulyak S, Hubbard T, Putnam D, Kearney DJ. Breath-Ammonia Testing of Healthy Subjects and Patients with Cirrhosis. Dig. Dis. Sci. 2005;50:1780-1784.

39. Kearney DJ. Hubbard T, Putnam D. Breath ammonia measurement in Helicobacter pylori infection. Ibid. 2002;47:2523-2530.

40. Gouma P, Kalyanasundaram K, Yun X, Stanaćević M, Wang L. Nanosensor and breath analyzer for ammonia detection in exhaled human breath. IEEE Sensors. 2010;10:49-53.

41. Adrover R,. D, Ridruejo E, Garcia A, Rome J, Podesta JJ. BreathAmmonia Testing of Healthy Subjects and Patients with Cirrhosis. Dig Dis Sci. 2012;57:189-195.

42. Mutshell D, Holzner K, Obermeier E. Sputtered molybdenum oxide thin films for $\mathrm{NH}_{3}$ detection. Sens. Actuators 1996;B35-36:320-324.

43. Imawan C, Solzbacher F, Steffes H, Obermeier EC. Ibid. 2000;B64:193-197.

44. Sunu S. S, Prabhu E, Jayaraman V, Gnanaseckar KI, Seshagiri K, Gnanasekaran T. Electrical conductivity and gas sensing properties of $\mathrm{MoO}_{3}$ Ibid. 2004;B101:161-174.

45. Sribastava V, Jain $\mathrm{K}$. Highly sensitive $\mathrm{NH}_{3}$ sensor using Pt catalyzed silica coating over $\mathrm{WO}_{3}$ thick films. Ibid. 2006;B133:46-52.

46. Jimenéz I, Centeno MA, Scotti R, Morazzoni F, Arbiol J, Cornet A, Morante J. R. $\mathrm{NH}_{3}$ interaction with chromium-doped $\mathrm{WO}_{3}$ nanocrystalline powders for gas sensing applications. J. Mater. Chem. 2004;14:2412-2420.

47. Zamani C, Casals O, Andreu T, Morante JR, Romano-Rodriguez A. Detecti:on of amines with chromium-doped $\mathrm{WO}_{3}$ mesoporous material. Sens. Actuators. 2009;B140:557-562.
48. Li HY, Huang L, Wang XX, Lee CS, Yoon JW, Zhou Z, Guo X, Lee J.-H. Molybdenum trioxide as a dual gas sensor for detecting trimethylamine and hydrogen sulfide. RSC Adv. 2017;7:3680-3685.

49. Cho TH, Kan YC, Lee J.-H. Highly selective and sensitive detection of trimethylamine using $\mathrm{WO}_{3}$ hollow spheres prepared by ultrasonic spray pyrolysis. Sens. Actuators. 2013;B176:971-977.

50. Sui LL, Xu YM, Zhang XF, Cheng XL, Gao S., H, Cai Z, Huo LH. In situ deposited hierarchical $\mathrm{CuO} / \mathrm{NiO}$ nanowall arrays film sensor with enhanced gas sensing performance to $\mathrm{H}_{2} \mathrm{~S}$. Ibid. 2018;B208:406-414.

51. Deng C, Zhang J, Yu X, Zhang W, Zhang X. Determination of acetone in human breath by gas chromatography-mass spectrometry and solidphase microextraction with on-fiber derivatization. J. Chromatogr. 2004;B810:269-275.

52. Španěl P, Dryahina K, Rejšková A, Chippendale TWE, Smith D. Breath acetone concentration: biological variability and the influence of diet. Physiol. Meas. 2011;32:N23-N31.

53. Kundu SK, Bruzek J. A, Nair R, Judilla, A. M. Breath acetone analyzer: Diagnostic tool to monitor dietary fat loss, Clin. Chem. 1993;39:92.

54. Choi SJ, Lee I, Jang BH, Youn DY, Ryu WH, Park CO, Kim I.-D. Selective diagnosis of diabetes using Pt-functionalized $\mathrm{WO}_{3}$ hemitube networks as a sensing layer of acetone in exhaled breath Anal. Chem. 2013;85:1792-1796.

55. Choi SJ, Kim SJ, Cho HJ, Jang JS, Lin YM,. Tuller H, et al. $\mathrm{WO}_{3}$ Nanofiber-Based Biomarker Detectors Enabled by ProteinEncapsulated Catalyst Self-Assembled on Polystyrene Colloid Templates. Small. 2016;12:911-920.

56. Kim SJ, Choi JJ, Jang JS, Kim NH, Hakim M, Tuller HL, Kim ID. Mesoporous $\mathrm{WO}_{3}$ Nanofibers with Protein-Templated Nanoscale Catalysts for Detection of Trace Biomarkers in Exhaled Breath. ACS Nano. 2016;10:5891-5899.

57. M. Righettoni, A. Tricoli, S. E. Pratsinis. Thermally Stable, SilicaDoped $\varepsilon-\mathrm{WO}_{3}$ for Sensing of Acetone in the Human Breath. Chem. Mater. 2010;22:3152-3157.

58. Righettoni M, Tricoli A, Gass S, Schmid A, Amann A, Pratsinis SE. Breath acetone monitoring by portable $\mathrm{Si}: \mathrm{WO}_{3}$ gas sensors. Anal. Chim. Acta. 2012;738:69-75.

59. Righettoni M, Tricoli A. Toward portable breath acetone analysis for diabetes detection J. Breath Res. 2011;5:037109-037117.

60. Jang JS, Choi SJ, Kim SJ, Hakim M, Kim ID. Rational Design of Highly Porous $\mathrm{SnO}_{2}$ Nanotubes Functionalized with Biomimetic Nanocatalysts for Direct Observation of Simulated Diabetes. Adv. Funct. Mater. 2016;26:4740-4748.

61. Shin J, Choi SJ, Lee I, Youn DY, Park CO, Lee JH, et al. Thin-wall assembled $\mathrm{SnO}_{2}$ fibers functionalized by catalytic Pt nanoparticles and their superior exhaled-breath-sensing properties for the diagnosis of diabetes. Adv. Funct. Mater. 2013;23:2357-2367.

62. Jang S, Choi SJ, Kim ID. Fast Responding Exhaled-Breath Sensors Using $\mathrm{WO}_{3}$ Hemitubes Functionalized by Graphene-Based Electronic Sensitizers for Diagnosis of Diseases. Sens. Actuators. 2017;B241:12761282.

63. Kim NH, Choi SJ, Kim SJ, Cho HJ, Jang J. S, Koo WT, Kim M, Kim ID. Highly sensitive and selective acetone sensing performance of $\mathrm{WO}_{3}$ nanofibers functionalized by $\mathrm{Rh}_{2} \mathrm{O}_{3}$ nanoparticles. Ibid. 2016;B224:85-192.

64. Koo WT, Yu S, Choi SJ, Jang JS, Cheong JY, Kim ID. Metal-Organic Framework-Templated $\mathrm{PdO}-\mathrm{Co}_{3} \mathrm{O}_{4}$ Nanocubes Functionalized by SWCNTs: Improved $\mathrm{NO}_{2}$ Reaction Kinetics on Flexible Heating Film. ACS Appl. Mater. Interfaces. 2017;9:8201-8210.

65. Aroutiounian V, Adamyan Z., Sayunts A, Khachaturyan E, Adamyan A, Hernadi K, et al. Comparative study of VOC sensors based on 
ruthenate MWCNT/SnO, nanocomposites. Int. Emerging Trends. Sci. Technology. 2014;1:1309-1319.

66. Rao J, Yu A, Shao C, Zhou X. Construction of Hollow and Mesoporous $\mathrm{ZnO}$ Microsphere: A Facile Synthesis and Sensing Property. ACS Appl. Mater. Interfaces. 2012;4:5346-5352.

67. Zhang F, Yang H, Xie X, Li L, Zhang L, Yu H, Zhao, H Liu FB. Controlled synthesis and gas-sensing properties of hollow sea urchinlike $\alpha-\mathrm{Fe}_{2} \mathrm{O}_{3}$ nanostructures and $\alpha-\mathrm{Fe}_{2} \mathrm{O}_{3}$ nanocubes. Sens. Actuator. 2009;B141:381-389.

68. Liang X, Kim TH, Yoon JW, Kwak CH, Lee JH. Ultrasensitive and ultraselective detection of $\mathrm{H}_{2} \mathrm{~S}$ using electrospun CuO-loaded $\mathrm{In}_{2} \mathrm{O}_{3}$ nanofiber sensors assisted by pulse heating. Ibid. 2015;B209:934-942.

69. Yoon JW, Hong YJ, Kang YC, Lee, JH. High performance chemiresistive $\mathrm{H}_{2} \mathrm{~S}$ sensors using Ag-loaded $\mathrm{SnO}_{2}$ yolk-shell nanostructures. RSC Adv. 2014;4:16067-16074.

70. Liu CH, Zhang L., He YJ. Properties and mechanism study of Ag doped $\mathrm{SnO}_{2}$ thin films as $\mathrm{H}_{2} \mathrm{~S}$ sensors, Thin Solid Films. 1997;304:13-15.

71. Ma S, Jia J, Tian Y, Cao L, Shi S, Li X, W ang X. Improved $\mathrm{H}_{2} \mathrm{~S}$ sensing properties of $\mathrm{Ag} / \mathrm{TiO}_{2}$ nanofibers. Ceram. Int. 2016;42:2041-2044.

72. Wang Y, Wang Y, Cao J, Kong F, Xia H, Zhang J, et al. Low-temperature $\mathrm{H}_{2} \mathrm{~S}$ sensors based on Ag-doped [alpha] $-\mathrm{Fe}_{2} \mathrm{O}_{3}$ nanoparticles. Sens. Actuator. 2008;B131:183-189.

73. Yoneda M, Suzuki N, Hirofuji T. Current Status of the Techniques Used for Halitosis Analysis. Austin Chromatogr. 2015;2:1024-1027.

74. Phillips M, Cataneo RN, Cummin ARC, Gagliardi AJ, Gleeson K, Greenberg J, et al. Detection of lung cancer with volatile markers in the breath. Chest. 2013;123:2115-2123.

75. Phillips M, Gleeson K, Hughes JMB, Greenberg H, Cataneo RN, Baker L. Volatile organic compounds in breath as markers of lung cancer: an across-sectional study. Lancet. 1999;353:1930-1933.

76. Peng G, Tisch U, Adams O, Hakim M, Schehada N, Broza YY, et al. Diagnosing lung cancer in exhaled breath using gold nanoparticles. Nat. Nanotech. 2009;4:669-673.

77. Fuchs R, Loeseken C, Shubert JK, Miekisch W. Breath gas aldehydes as biomarkers of lung cancer. Int. J. Cancer. 2010;126:2663-2670.

78. Chen X, Xu F, Wang Y, Pan Y, Lu D, Wang P., et al. WA study of the volatile organic compounds exhaled by lung cancer cells in vitro for breath diagnosis. Cance. 2007;10:835-844.

79. Hakim M, Broza Y, Barash O, Peled N, Phillips M, Amann A, Haick H. Volatile organic compounds of lung cancer and possible biochemical pathways. Chem. Rev. 2012;112:5949-5966.

80. Aroutiounian V, Adamyan Z, Sayunts A, Khachaturyan E, Adamyan A, Vrnata M, et al. Study of propylene glycol, dimethylformamide and formaldehyde vapors sensors based on MWCNTs $/ \mathrm{SnO}_{2}$ nanocomposites. Sens. Transd. 2017;213:38-45.

81. Aroutiounian VM, Hydrogen sensors, Dekker Encyclopedia of Nanoscience and Nanotechnology, Second Edition, Taylor and Francis, USA, 2012, 1-10.

82. Aroutiounian VM, Arakelyan VM, Khachaturyan EA, Shahnazaryan
GE, Aleksanyan MS, Hernadi K, et al. Manufacturing and investigations of i-butane sensor made of $\mathrm{SnO}_{2} /$ multiwall-carbonnanotube nanocomposite. Sens. Actuators. 2012;B173:890-896.

83. Aroutiounian VM, Adamyan AZ, Adamyan ZN, Khachaturyan EA., Hernadi K, Pallai Z, et al. Study of the surface-ruthenate $\mathrm{SnO}_{2} / \mathrm{MWCNTs}$ nanocomposite thick-film gas sensors. Ibid. 2013;B177:308-315.

84. Aroutiounian VM, Porous silicon gas sensors. In Semiconductor gas sensors, Woodhead Publishing Series in Electronic and Optical Materials N 38, Chapter 12, 2013, 408-430.

85. Aroutiounian VM, Arakelyan VM, Shahnazaryan GE, Aleksanyan MS, Hernadi K, Nemeth Z Berki P. The ethanol sensors made from $\alpha-\mathrm{Fe}_{2} \mathrm{O}_{3}$ decorated with multiwall carbon nanotubes. Advances in Nano Research 2015;1:1-11.

86. Aroutiounian VM, Metal oxide gas sensors decorated with carbon nanotubes. Lithuanian Journal of Physics. 2015;55:319-329.

87. Aroutiounian VM. Graphene- and graphene-oxide-based gas sensors. Graphene Science Handbook. Applications and Industrialization. CRC Press Tailor and Francis Group, USA, Fl., Boca Raton, Chapter 20, 2016, 299-310.

88. Aroutiounian VM, H. Zakaryan. CO gas adsorption on $\mathrm{SnO}_{2}$ surfaces: density functional theory study. Sens. Transducers. 2017;212:50-56.

89. Aroutiounian V, Arakelyan V, Aleksanyan M, Sayunts A, Shahnazaryan G, Kacer P, et al. Ibid. 2017;213:46-53.

90. Aroutiounian V, Arakelyan V, Aleksanyan M, Sayunts A, Shahnazaryan G, Vrnata M, et al. Sensor for detection of chemical agents made of Co-doped $\mathrm{SnO}_{2}$. Arm. J. Phys. 2017;10:122-127.

91. Aroutiounian V, Properties of hydrogen peroxide sensors made from nanocrystalline materials. Sens. Transducers. 2018;223:9-21.

92. Aroutiounian VM. Semiconductor gas sensors for detection of chemical warfare agents and toxic industrial chemicals. Intl Sci J Alternative Energy and Ecology. 2018;249-251:38-48.

93. Aroutiounian V, Adamyan Z, Sayunts A,. Khachaturyan E, Vrnata M, Fitl P, Vlček. J. Sens. Sens. Syst. 2018;7:31-41.

94. Aroutiounian V, Arakelyan V, Aleksanyan M, Sayunts A, Shahnazaryan $\mathrm{G}$, Kacer P, et al. Thin-film $\mathrm{SnO}_{2}$ and $\mathrm{ZnO}$ detectors of hydrogen peroxide vapors. J. Sens. Sens. Syst. 2018;7:281-288.

95. Aroutiounian V, Adamyan Z, Sayunts A, Khachaturyan E, Arakelyan $\mathrm{V}$, Joost B. Nanocomposite $\mathrm{H}_{2} \mathrm{O}_{2}$ vapor sensors made on the base of carbon nanotubes covered with $\mathrm{SnO}_{2}$ nanoparticles. Sens. Transducers. 2019;229:18-23.

96. Aroutiounian V, Arakelyan V, Aleksanyan M, Sayunts A, Shahnazaryan G, Joost B. Study of hydrogen peroxide vapors sensor made of nanostructured Co-doped $\mathrm{SnO}_{2}$ film. Ibid. 2019;229:24-31.

97. Aroutiounian V, Kirakosyan V. Flexible gas detector Arm. J. Phys. 2018;11:160-165.

98. Aroutiounian VM, Hovhannisian A. Semiconductor gas sensors detector using Arduino NANO. Ibid. 2019;12:283-287.

99. Aroutiounian V, Pokhsraryan D, Chilingaryan H. Gas monitoring system. Ibid. 2010;3:78-81. 